\title{
Morphological characteristics and physical environment of Terminalia catappa in East Kalimantan, Indonesia
}

\author{
MARJENAH $^{1, \boldsymbol{\nu}}$, NOVY PRALISA PUTRI ${ }^{2}$ \\ ${ }^{1}$ Silviculture Laboratory, Faculty of Forestry, Universitas Mulawarman. Kampus Gunung Kelua. Jl. Ki Hajar Dewantara P.O. Box 1013 Samarinda \\ 75116, East Kalimantan, Indonesia. Tel.: +62-541-735 089, 749 068; Fax.: +62-541-735 379; `email: marjenah-umar@yahoo.com \\ ${ }^{2}$ Chemical Engineering Laboratory, Faculty of Engineering, Universitas Mulawarman. Samarinda 75116, East Kalimantan, Indonesia
}

Manuscript received: 5 February 2017. Revision accepted: 17 June 2017.

\begin{abstract}
Marjenah, Putri NP. 2017. Morphological characteristics and physical environment of Terminalia catappa in East Kalimantan, Indonesia. Asian J For 1: 33-39. Tropical almond (Terminalia catappa) is a large tree and is widely distributed throughout the tropics, especially in coastal environments. This plant has the potentials to be developed intensively as forestry commodity since the timber can be made into a useful and decorative general-purpose hardwood and is well suited for conversion into furniture and interior building timbers. Yet, there is limited knowledge on its ecological performance regarding the environments where it grows. Therefore, this research aimed to determine the growth of T. catappa in varying altitudinal ranges in three locations in East Kalimantan, Indonesia and to investigate the relationship among morphological characteristics and environmental factors. The results of statistical analysis showed that differences in altitudinal ranges had no significant effects on the growth of stem diameter, angle of branching, and width of canopy closure. Meanwhile, the analysis on stem height and radius of canopy showed highly significant differences. The exploration and characterization of T. catappa plants are still needed to reveal the potentials of its germplasm to be developed as forestry plants and not only for ornamental purposes.
\end{abstract}

Keywords: tropical almond, morphological characteristics, physical environment, flowering and fruiting,

\section{INTRODUCTION}

Tropical almond (Terminalia catappa $\mathrm{L}$.) is a large tree and is widely distributed throughout the tropics especially in coastal areas. T. catappa belongs to the family Combretaceae (Combretum family) and is locally called "Abrofonkate" (Whiteman's peanut). The tree is tolerant to strong winds, salt exposure, and moderately high salinity in the root zone. It grows principally in freely drained and well-aerated sandy soils.

The species has traditionally been very important for coastal communities, providing a wide range of non-wood products and services. It has a spreading, fibrous root system and plays a vital role in coastline stabilization. It is widely planted throughout the tropics, especially along sandy seashores for shade and ornamental purposes (Akpakpan and Akpabio 2012). The timber makes a useful and decorative general-purpose hardwood and is well suited for conversion into furniture and interior building timbers. The nuts are edible and fruits are produced from tree about 3 years of age, and the nutritious, tasty seed kernels may be eaten immediately after extraction (Thomson and Evans 2006). Its fruits and seeds have also medicinal properties

T. catappa is slightly deciduous during dry season, and in some environments may lose its leaves twice a year (Thomson and Evans 2006). Raju et al. (2012) recorded information that $T$. catappa changes foliage twice a year, once during February-March and the second during June-
August, each time with the shedding leaves and new foliage puts forth

It is a perennial tree reaching a height of $15-25 \mathrm{~m}$ and about $9 \mathrm{~m}$ in width of its symmetrical canopy. The leaves are arranged in close spirals. The leaf blade is simple broadly obovate, the leaf top is round and obtuse, gradually oval to a narrowing substrate base. The leaves change their color from green to red, yellow or gold and copper brown during the dry season and then they fell off. The greenishyellow leaves are clustered in axillary spikes, small, and inconspicuous.

The plant forms layers of canopy and branches which bear clusters of fruits. It usually commences flowering within 2-3 years of out planting but this may vary with site and genotype (Oboh, et al. 2008). The fruits which consist of the epicarp, fleshy mesocarp, stony mesocarp, and fibrous endocarp enclosing the seed, and kernel are ovoid in shape, laterally compressed with various sizes and colors at maturity (Thomson and Evans 2006). The T. catappa tree has a conservative estimated yield of $75 \mathrm{~kg}$ of fruits per year, which has long been wasted in the field (Apata 2011).

The $T$. catappa tree produces fruits that pulp is fibrous, sweet, and edible when ripe. The fruit is widely eaten by children as forage snack with the nuts and seeds often discarded (Henn et al. 2014). In the Bahamas, children seek out the trees with the most palatable fruits and these are the ones with the most colorful skin and with reddish or pink tones extending through the flesh corky surface of the "nut" (Morton 1985). 
The altitudinal distribution of plant species over the earth's surface could be described as phytogeography, which tends to reflect the dynamic trend of species richness and diversity. Such trend of amplitude does imply biological barrier that creates biotic difference on the natural biota with variation in the morpho-anatomical structures in relation to agro-climatic and environmental influences that dictate such macrophytic amplitude (Edwins-Wosu, et al. 2013). Variation in species richness in relation to species-latitude and species-area relationship with elevation has been known for over a century.

Several studies have found a decreasing trend in species richness with increasing elevation, whereas others found a hump-shaped relationship between species richness and elevation. This argument is further supported by the fact that landscapes are never static, and their elements are in permanent temporal and spatial flux. The elevation gradient in species richness pattern is commonly explained by similar factors such as climatic, productivity, and other energy-related factors (Wosu, et al. 2013).

In spite of the information on the phytogeographical trend of $T$. catappa, data on its ecological amplitude or diversity distribution are either not available or scanty. In light of this inadequacy, the objectives of this research were: (i) to determine the growth of $T$. catappa in varying altitudinal ranges, (ii) to investigate the relationship among morphological characteristics and environmental factors.

\section{MATERIALS AND METHODS}

\section{Study period and area}

This study was conducted from January to May 2017 in three locations in East Kalimantan Province, namely Balikpapan City, Samarinda City, and Kutai Kartanegara District to represent habitats with varying altitudes and environmental conditions.

One hundred and eighteen trees of $T$. catappa were randomly selected from the three locations. The trees selected as the research objects are trees that grow solitary planted on the roadside as shade plants because in East Kalimantan there is no stand of T. catappa that is planted as manmade forest.

\section{Sampling procedure}

At the sampling locations (Samarinda, Tenggarong, Balikpapan) 118 trees of $T$. catappa were determined as research objects. The sampling stages are as follows: (i) Determining the elevation of the site, measured as meter above sea level ( $\mathrm{m}$ asl); (ii) Determining the sampled tree, measured as tree with minimum $10 \mathrm{~cm}$ in diameter at a height of $1.3 \mathrm{~m}$ from the ground; (iii) Measuring the width of the crown of the sampled tree which covers projections according to each of the four main points to the compass (North, South, East, and West); (iv) Observing the color of leaves; (v) Measuring length, width of leaves, petiole and leaf area.

\section{Data collection}

\section{Morphological characteristics}

Tree data were collected including location, height, diameter at breast height, canopy shape/width of header. Leaves data included leaf area, length, and width of leaves, leaf color (old, young), leaf texture, petiole angle, primary branch angle. Data of fruit were fruit shape, old fruit color, tip/base of fruit, diameter and length of fruit stalk $(\mathrm{cm})$, period of flowering/fruit, length/width/circumference of fruit, fruit weight. Length and width of leaf measurements were taken using metric rule, leaf area using a square centimeter unit while weights were determined using a weighing balance.

\section{Physical environmental characteristics}

Observations/measurements of temperature and humidity of air in the field/under the canopy were done once in each sample tree using thermohydrometer; Measurement of light intensity is performed on every tree sample using Illuminometer. In each sample tree, we measured altitude of place and position, slope of land, and soil $\mathrm{pH}$.

The altitudinal ranges where the $T$. catappa grew were grouped into 9 groups of elevation, namely: $0-10 \mathrm{~m}$ asl; $11-$ $20 \mathrm{~m}$ asl; 21-30 $\mathrm{m}$ asl; 31-40 $\mathrm{m}$ asl; 41-50 m asl; 51-60 m asl; 61-70 m asl; 71-80 m above sea level; And 81 -> $90 \mathrm{~m}$ asl (Table 1).

\section{Data analysis}

All the data were presented as mean \pm SD (standard deviation). Statistical comparisons were performed using Analysis of Variance (ANOVA with differences were considered significant at $\mathrm{p}<0.05$.

\section{RESULTS AND DISCUSSION}

The research on $T$. catappa trees in the three locations obtained 118 trees occurred on the elevation from 0 to 90 $\mathrm{m}$ asl. The distribution of the sampled trees based on altitudinal ranges is presented in Table 1 .

Table 1. The distribution of the sampled trees based on elevation (m asl)

\begin{tabular}{lc}
\hline Elevation $(\mathbf{m}$ asl) & Number of trees \\
\hline $0-10$ & 17 \\
$11-20$ & 30 \\
$21-30$ & 20 \\
$31-40$ & 15 \\
$41-50$ & 4 \\
$51-60$ & 15 \\
$61-70$ & 5 \\
$71-80$ & 5 \\
$81->90$ & 7 \\
Total & 118 \\
\hline
\end{tabular}


Variations in a plant can be observed from various aspects. One is a morphological feature that is easily observed by naked eye or is called macromorphologically. Macromorphological characters as taxonomic evidence have advantages. Although there are other taxonomic evidence, such as micromorphology, anatomy, biochemistry, etc., but they are generally uneven and completed for the taxon group, moreover they are not as detailed as they are, and also their numbers are inadequate, so their uses to construct a classification system are generally less efficient because they are difficult to coordinate. Therefore, for everyday purposes, the criteria of morphological characters continue to be the main focus of determination activities, the establishment, and the preparation of a practical classification system (Setyawan 1999). The variation of the morphological characteristics of T. catappa trees is shown in Table 2.

Results showed that there was a large variation in most of the characters examined. Leaf length ranged from 19.5 to $42.5 \mathrm{~cm}$ with a mean value of $29.7 \mathrm{~cm}$, which is larger than that in South Western Nigeria with $8.58 \mathrm{~cm}$ to $17.3 \mathrm{~cm}$ with a mean $14.2 \mathrm{~cm}$ (Oboh, et al. 2008). The leaves of tropical almond tree are quite big. Usually, they are thick and leathery with an ovoid shape and glossy dark green color. Before shedding its leaves to survive the dry season, the Tropical almond tree will retract the valuable green pigmentation, leaving the leaves pinkish-reddish or yellowbrown (Figure 1).

Traditionally, only the fallen leaves of $T$. catappa are boiled or brewed as a drink (tea). These leaves have been used in folk medicine as an antidiarrheal and antipyretic in India, Philippines, and Malaysia. In Taiwan, it has been used to prevent liver tumors and to treat hepatitis (dosSantos, et al. 2016)

Shedding of the leaves takes place twice a year, first on January/February/March and second, on July/August/ September. Such 'autumn leaves' are very rare in the tropics. After the crown is bare, all the twigs develop new leaves and the tree is fresh green. The tree then flowers after the new leaves have developed. According to Hayward (1990) about the flushing mark during flowering, especially from October to January, it is claimed that the reddish change and leaf-shedding was driven by drizzling rain due to relative humidity, although this relationship is not measured. T. catappa leaf color changes were identified during research activity and it is shown in Figure 2.

Along with the appearance of new leaves, generative shoots are also beginning to come out. Many tiny white flowers emerge on long spikes. The Almond tree produces drupe fruits, just like the true almond and many other famous plants, e.g. mango, date, and coffee. A drupe is a fruit characterized by having an outer fleshy part that wraps a shell inside containing a seed. In drupes, the hard shell, commonly referred to as pit, develops from the ovary wall of the flower. Terminalia catappa is andromonoecious and its inflorescences bear bisexual flowers at the bottom and staminate ones above. Three types of inflorescence occur and this classification is based on their length. Of all the three types of inflorescence, $30 \%$ bear only male flowers whereas the rest bears both bisexual and male flowers (Raju 2012).

Table 2. Range of variation in morphological characteristics of Terminalia catappa $\mathrm{L}$. observed in this study.

\begin{tabular}{lll}
\hline Characters & Range & Mean \pm SD \\
\hline Leaf length $(\mathrm{cm})$ & $19.5-42.5$ & $29.7 \pm 5.4$ \\
Leaf width $(\mathrm{cm})$ & $10.3-21.0$ & $16.1 \pm 3.0$ \\
Leaf area $\left(\mathrm{cm}^{2}\right)$ & $149.0-508.0$ & $311.8 \pm 105.5$ \\
Petiole length $(\mathrm{cm})$ & $1.0-3.5$ & $1.9 \pm 0.6$ \\
Fruit length $(\mathrm{cm})$ & $4.46-6.71$ & $5.8 \pm 0.6$ \\
Fruit width $(\mathrm{cm})$ & $3.32-4.19$ & $3.9 \pm 0.3$ \\
Fruit circumference $1(\mathrm{~cm})$ & $10.65-15.50$ & $14.0 \pm 1.38$ \\
Fruit circumference 2 $(\mathrm{cm})$ & $9.8-12.55$ & $11.0 \pm 0.65$ \\
Fresh fruit weight $(\mathrm{g})$ & $16.43-30.55$ & $25.0 \pm 4.29$ \\
Dry seed weight $(\mathrm{g})$ & $5.06-7.33$ & $6.0 \pm 0.76$ \\
Number of fruit $/ \mathrm{kg}$ & $33-64$ & $43 \pm 9$ \\
Stem diameter $(\mathrm{cm})$ & $18.2-61.4$ & $33.9 \pm 11.7$ \\
Branching angle $\left({ }^{\circ}\right)$ & $20-85$ & $61 \pm 20$ \\
Total height $(\mathrm{m})$ & $6.9-23.8$ & $14.0 \pm 5.0$ \\
Bole height $(\mathrm{m})$ & $1.1-6.6$ & $3.0 \pm 1.0$ \\
Canopy height $(\mathrm{m})$ & $2.7-21.3$ & $11.0 \pm 4.0$ \\
Canopy radius $(\mathrm{m})$ & $4.7-11.3$ & $7.6 \pm 1.5$ \\
Crown cover area $\left(\mathrm{m}^{2}\right)$ & $67.9-397.6$ & $188.1 \pm 70.6$ \\
\hline
\end{tabular}

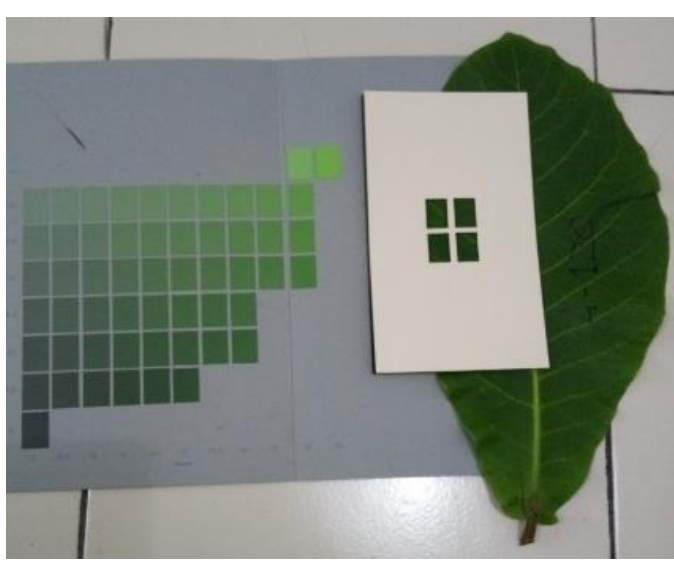

A

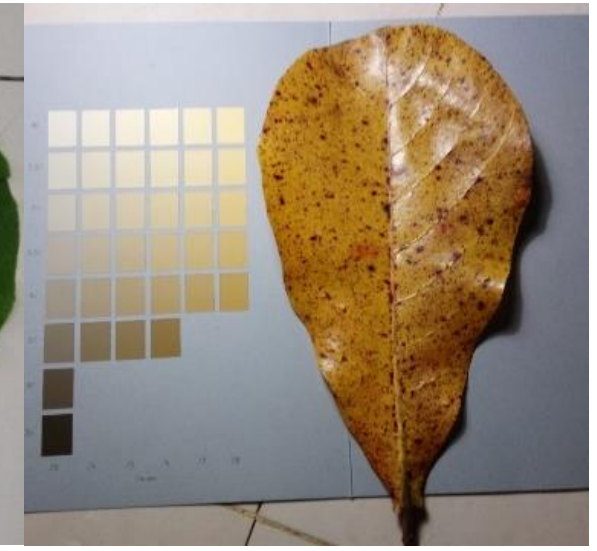

B

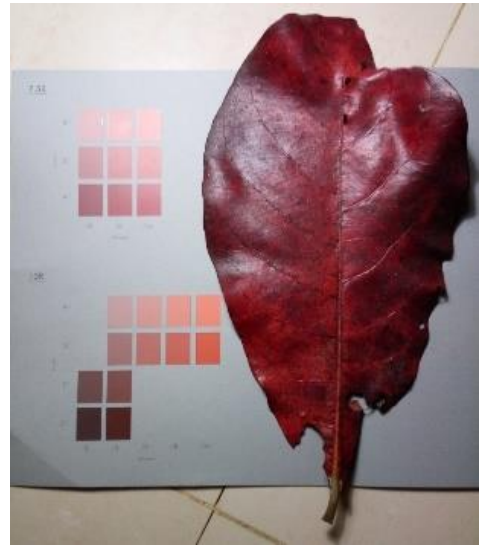

C

Figure 1. Phase of leaf color change (Photograph by Marjenah 2017). A. 7.5 GY 4/5: Dull green, B. 7.5 YR 7/8: Dull yellowish-orange, C. 7.5 RP 4/10: Strong red-purple 


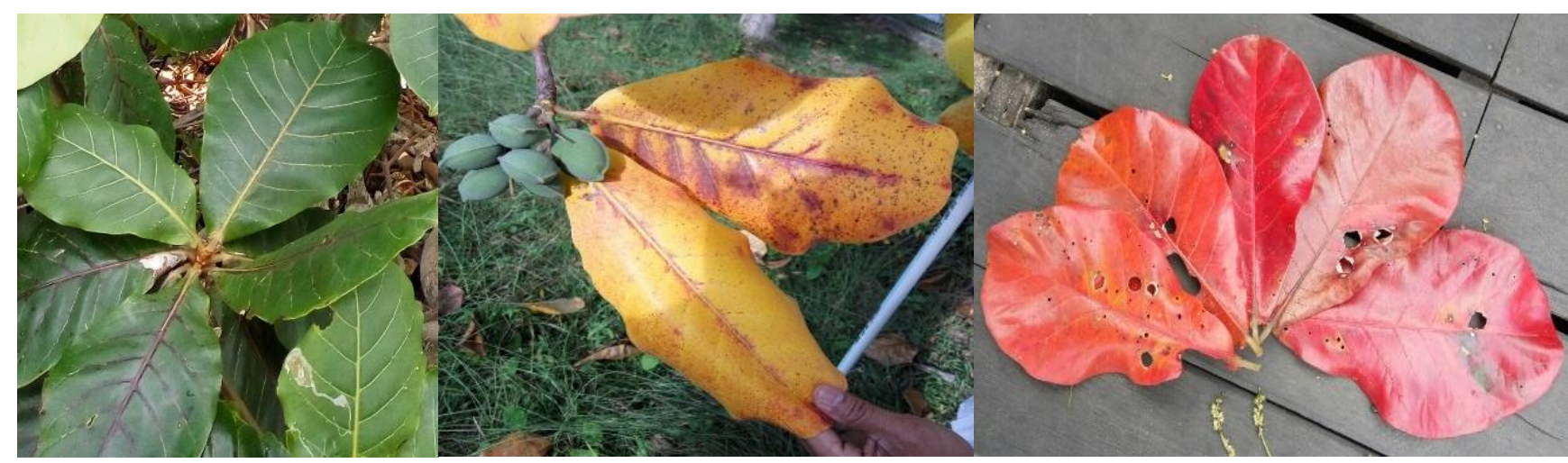

Figure 2. Terminalia catappa leaf color change identified during this research (Photograph by Marjenah 2017)

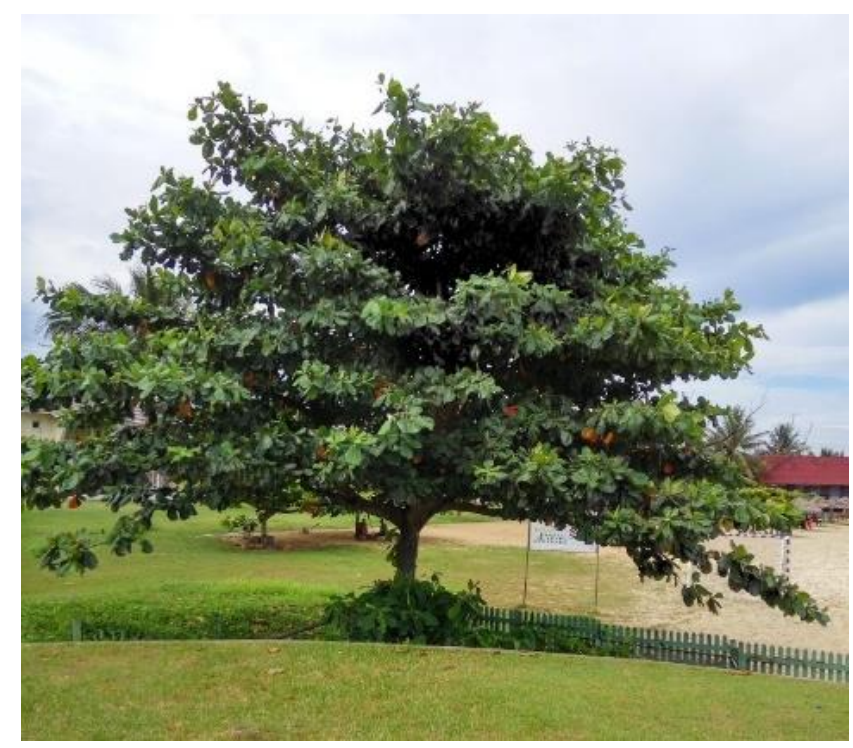

Figure 4. Terminalia catappa (Tropical almond tree) planted on the beach in Balikpapan, East Kalimantan, Indonesia (Photograph by Marjenah 2017)

The fruit is 4.46 to $6.71 \mathrm{~cm}$ length, 3.32 to $4.19 \mathrm{~cm}$ width, ellipsoid, more pointed at the apex than at the base, slightly flattened, with a prominent base around both sides and at the tip, whereby this form contributes to its ability to float in a long distance in the sea. A seed will be found inside the fruit and a fully ripe seed is edible. It tastes similar to almond, hence it is named like that. The seed is ready to eat when the fruit turns red. Just like many other fruits and berries, the almond tree fruit is green at first, then yellow, and finally red when ripe (Figure 3 ).

Table 3 shows the morphological variation of $T$. catappa plants based on the elevation of the growing site. From the result of statistical analysis of $T$. catappa morphological characteristics at various elevations, it is known that the growth of stem diameter, angle of branching, and width of canopy closure showed no significant results. Meanwhile, the analysis on stem height and radius of canopy showed highly significant results.

The effect of plant canopy on the microclimate is, directly and indirectly, related to the existence of crowns and stems. Branches and leaves reflect the sunray and absorb some of the solar radiation during the day, allowing less energy to reach the ground below the canopy (Arx 2012).

The trees that grew solitary in the open area (Figure 4) produce more seeds than those that grew in shaded areas. This extraordinary capacity to produce more beans is likely due to the availability of large amount of carbohydrates as a result of the high photosynthetic activity in the open area. The crops may be affected by environmental factors and this may limit the use of morphological characters especially since they tend to carry over the effect of climatic factors.

Elevation is one of the most influential factors on crop growth and yield. There is a close relationship between elevation and climate especially air temperature. The lower elevation the higher the air temperature. High or low air temperature is closely related to the irradiation conditions in the area. Light intensity acceptance as a growth factor is strongly influenced by this competition. The reduction of light intensity is usually followed by a decrease in the number of branches of the plant. Because of low light intensity, the plant grows higher, since the results of Photosynthesis used for establishment of branches are only in small amount, consequently, the number of branches is small too. Increasing light intensity will increase the process of photosynthesis in plants, because sunlight is a source of energy for photosynthesis.

Leaf area is the morphological characteristic commonly used to determine the development of the canopy. Leaf canopy structure, especially of leaf angle, is relative to vertical line. Plants with horizontal leaves proceed 30-40\% of the light coming through each unit of index of leaf area, while the upright leaves can proceed $45-65 \%$ of the light. With leaves that are perpendicular to sunlight on bright sunlight, the growth rate of the crop will be theoretically enhanced by the spreading of the more evenly distributed light in the canopy with upright leaves (Goldsworthy and Fisher 1992).

The physical environmental variables based on elevation is shown in Table 4. Physical environment characteristics observed were light intensity, air temperature, relative humidity, soil temperature and $\mathrm{pH}$. 
Statistical analysis of physical environment characteristics of $T$. catappa trees based on elevation shows that the light intensity and relative humidity are not significant. On the other hand, air temperature, soil temperature, and $\mathrm{pH}$ are highly significant.

The average air temperature at the low elevation site was $29.8 \pm 1.06^{\circ} \mathrm{C}$ while in higher elevation areas $(>90 \mathrm{~m}$ asl) was $28 \pm 1.4^{\circ} \mathrm{C}$. According to Ewusie (1990), air temperature decreased to follow altitude on high mountains. In the tropics, the average temperature decreases about $0.4^{\circ} \mathrm{C}$ for every $100 \mathrm{~m}$ increase. The occurrence of decreased air temperature is related to escalation of elevation. The temperature difference is assumed that there are also differences in growth and phenological characteristics.

Groundwater and enough nutrients will cause an increase in metabolic activity of the plant. This will support the growth of the plant, so that the crop yield or quantity will increase. The process of photosynthesis, respiration, and transpiration will also increase (if there were no limiting factors) at higher temperatures. The air temperature will drop at a higher altitude.

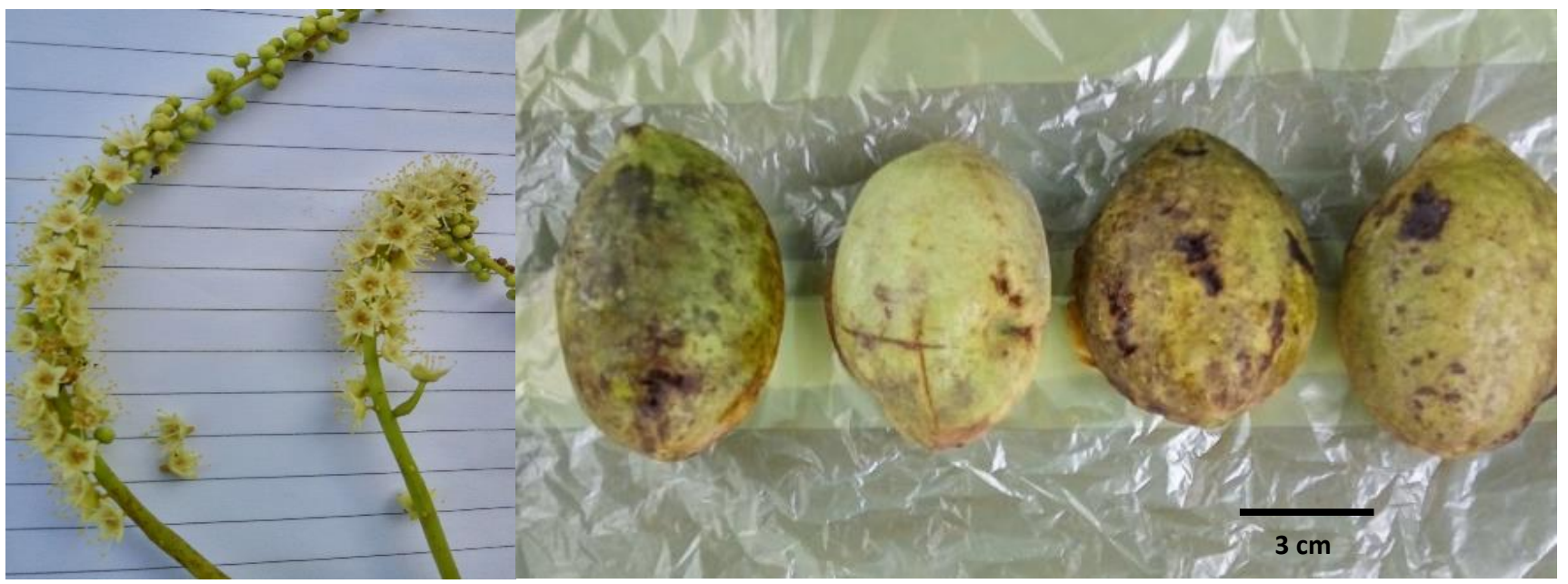

Figure 3. Flower and fruit of tropical almond in Tenggarong, Kutai Kartanegara district, East Kalimantan, Indonesia (Photograph by Marjenah 2017)

Table 3. Morphological characteristics of Terminalia trees based on altitudinal ranges

\begin{tabular}{|c|c|c|c|c|c|c|}
\hline $\begin{array}{l}\text { Elevation } \\
(\mathrm{m} \text { asl) }\end{array}$ & $\begin{array}{c}\text { Number } \\
\text { of trees }\end{array}$ & $\begin{array}{l}\text { Diameter }(\mathbf{c m}) \\
\text { range average }\end{array}$ & $\begin{array}{l}\text { Angle of branching } \\
\left({ }^{\circ}\right) \text { range average }\end{array}$ & $\begin{array}{c}\text { Height }(\mathbf{m}) \\
\text { range average }\end{array}$ & $\begin{array}{l}\text { Radius of canopy } \\
(\mathrm{m}) \text { range average }\end{array}$ & $\begin{array}{l}\text { Wide of canopy closure } \\
\left(\mathrm{m}^{2}\right) \text { range average }\end{array}$ \\
\hline \multirow[t]{2}{*}{$0-10$} & 17 & $17.9-50.3$ & $30-84$ & $6.9-22.9$ & $3.3-8.0$ & $8.7-202.3$ \\
\hline & & $30.5 \pm 9.95$ & $58.4 \pm 19.70$ & $15.7 \pm 4.53$ & $5.7 \pm 1.43$ & $80.1 \pm 69.90$ \\
\hline \multirow[t]{2}{*}{$11-20$} & 30 & $20.8-50.9$ & $26-86$ & $8.9-26.2$ & $2.7-8.7$ & $5.8-261.6$ \\
\hline & & $30.7 \pm 9.58$ & $54.6 \pm 19.78$ & $16.8 \pm 5.16$ & $5.4 \pm 1.95$ & $102.8 \pm 86.5$ \\
\hline \multirow[t]{2}{*}{$21-30$} & 20 & $12.8-52.7$ & $25-87$ & $7.7-22.1$ & $3.1-8.8$ & $7.5-244.0$ \\
\hline & & $26.7 \pm 11.33$ & $57.9 \pm 23.01$ & $13.8 \pm 3.97$ & $5.3 \pm 1.63$ & $78.3 \pm 69.55$ \\
\hline \multirow[t]{2}{*}{$31-40$} & 15 & $16.2-58.6$ & $30-85$ & $6.4-27.1$ & $3.7-8.5$ & $10.6-227.0$ \\
\hline & & $30.3 \pm 12.22$ & $54.0 \pm 18.42$ & $16.1 \pm 5.63$ & $6.0 \pm 1.65$ & $104.7 \pm 80.36$ \\
\hline \multirow[t]{2}{*}{$41-50$} & 4 & $20.2-48.4$ & $30-90$ & $12.2-15.8$ & $4.6-7.3$ & $16.8-82.5$ \\
\hline & & $28.6 \pm 13.3$ & $47.5 \pm 28.7$ & $14.3 \pm 1.5$ & $6.0 \pm 1.3$ & $44.6 \pm 27.5$ \\
\hline \multirow[t]{2}{*}{$51-60$} & 15 & $12.2-56.8$ & $36.0-85.0$ & $8.6-23.8$ & $3.2-9.5$ & $8.2-285.0$ \\
\hline & & $32.3 \pm 13.0$ & $58.0 \pm 16.5$ & $15.9 \pm 4.6$ & $7.0 \pm 2.0$ & $159.5 \pm 93.8$ \\
\hline \multirow[t]{2}{*}{$61-70$} & 5 & $21.8-31.2$ & $30-40$ & $13.3-16.7$ & $3.5-6.6$ & $37.9-134.8$ \\
\hline & & $25.6 \pm 3.5$ & $34.8 \pm 4.1$ & $14.8 \pm 1.4$ & $5.3 \pm 1.3$ & $91.1 \pm 40.0$ \\
\hline \multirow[t]{2}{*}{$71-80$} & 5 & $19.2-48.8$ & $30-85$ & $9.3-23.7$ & $6.2-7.9$ & $120.8-193.6$ \\
\hline & & $31.0 \pm 11.1$ & $63.2 \pm 26.2$ & $15.4 \pm 5.3$ & $7.1 \pm 0.8$ & $158.4 \pm 34.3$ \\
\hline \multirow[t]{2}{*}{$81->90$} & 7 & $21.1-54.0$ & $36-83$ & $7.9-24.3$ & $3.6-14.0$ & $3.6-14.0$ \\
\hline & & $32.9 \pm 13.4$ & $63.2 \pm 23.1$ & $14.7 \pm 6.4$ & $7.4 \pm 4.1$ & $203.7 \pm 186.4$ \\
\hline Fcal & & 1.25 & 0.10 & 8.48 & 10.91 & 0.002 \\
\hline $\mathrm{Ftab}(0.05)$ & & 2.45 & & & & \\
\hline $\operatorname{Ftab}(0.01)$ & & 3.49 & & & & \\
\hline Significance & & ns & ns & $* *$ & $* *$ & ns \\
\hline
\end{tabular}


Table 4. Physical environment variables of Terminalia catappa growing site

\begin{tabular}{|c|c|c|c|c|c|c|}
\hline $\begin{array}{c}\text { Elevation } \\
(\mathbf{m} \text { asl) }\end{array}$ & $\begin{array}{c}\text { Number } \\
\text { of trees }\end{array}$ & $\begin{array}{c}\text { Light intensity (\%) } \\
\text { range average }\end{array}$ & $\begin{array}{c}\text { Air temperature } \\
\left({ }^{\circ} \mathrm{C}\right) \text { range average }\end{array}$ & $\begin{array}{l}\text { Relative humidity } \\
(\%) \text { range average }\end{array}$ & $\begin{array}{c}\text { Soil temperature } \\
\left({ }^{0} \mathrm{C}\right) \text { range average }\end{array}$ & $\begin{array}{c}\mathrm{pH} \\
\text { Range average }\end{array}$ \\
\hline \multirow[t]{2}{*}{$0-10$} & 17 & $12-53.2$ & $28.8-31.4$ & $72-95$ & $26-28$ & $6-9$ \\
\hline & & $27.5 \pm 10.38$ & $29.8 \pm 1.06$ & $80.8 \pm 12.1$ & $27.2 \pm 0.6$ & $7.5 \pm 1.5$ \\
\hline \multirow[t]{2}{*}{$11-20$} & 30 & $26.8-59.1$ & $28.9-34.1$ & $81-90$ & $27-31$ & $5-10$ \\
\hline & & $44 \pm 14$ & $29.7 \pm 2.6$ & $85.5 \pm 14.4$ & $27.9 \pm 1.4$ & $7 \pm 2$ \\
\hline \multirow[t]{2}{*}{$21-30$} & 20 & $14.8-39.2$ & $26-35.1$ & $76-90$ & $27-28$ & $5-10$ \\
\hline & & $29 \pm 7.2$ & $28.3 \pm 2.7$ & $83 \pm 9.9$ & $27.3 \pm 0.5$ & $6.8 \pm 1.5$ \\
\hline \multirow[t]{2}{*}{$31-40$} & 15 & $12.2-70.9$ & $26-33.1$ & $74-82$ & $26-32$ & $5-12$ \\
\hline & & $35.75 \pm 20.1$ & $28.8 \pm 2.7$ & $79.6 \pm 3.3$ & $27.7 \pm 2$ & $7.3 \pm 2.4$ \\
\hline \multirow[t]{2}{*}{$41-50$} & 4 & $12.1-38.9$ & 28.1-30.7 & $72-79$ & $27-28$ & $6-8$ \\
\hline & & $22.8 \pm 11.8$ & $29.1 \pm 1.4$ & $74.3 \pm 4.0$ & $27.3 \pm 0.6$ & $7 \pm 0.8$ \\
\hline \multirow[t]{2}{*}{$51-60$} & 15 & $11.5-40.8$ & $26-31.6$ & $76-92$ & $27-31$ & $4-11$ \\
\hline & & $28.9 \pm 9.2$ & $28.8 \pm 2.6$ & $82 \pm 7.7$ & $28.2 \pm 1.2$ & $6.6 \pm 2.6$ \\
\hline \multirow[t]{2}{*}{$61-70$} & 5 & $18.7-23.8$ & $27-31.6$ & $71-90$ & $26-28$ & $4-9$ \\
\hline & & $20.5 \pm 2.3$ & $28.8 \pm 2.5$ & $81 \pm 9.5$ & $26.8 \pm 1.0$ & $6 \pm 2.4$ \\
\hline \multirow[t]{2}{*}{$71-80$} & 5 & $18.3-30.6$ & $27-29.5$ & $71-86$ & $26-29$ & $5-8$ \\
\hline & & $23.5 \pm 5.2$ & $28.6 \pm 1.1$ & $77.2-6.4$ & $27.6 \pm 1.3$ & $6 \pm 1.4$ \\
\hline \multirow[t]{2}{*}{$81->90$} & 7 & $13.0-49.5$ & $26-29$ & $75-90$ & $28-29$ & $5-10$ \\
\hline & & $30.0 \pm 15.2$ & $28 \pm 1.4$ & $80.6 \pm 5.8$ & $28.8 \pm 0.5$ & $7.5 \pm 2.4$ \\
\hline Fcal & & 0.14 & 21.86 & 0.72 & 20.90 & 23.37 \\
\hline $\operatorname{Ftab}(0.05)$ & & & & 2.45 & & \\
\hline $\operatorname{Ftab}(0.01)$ & & & & 3.49 & & \\
\hline Significance & & $\mathrm{ns}$ & $* *$ & $\mathrm{~ns}$ & $* *$ & $* *$ \\
\hline
\end{tabular}

The crops may be affected by environmental factors and this may limit the use of morphological characters especially since they tend to carry over the effect of climatic factors. Weather conditions affect seed production by influencing the formation of flower buds and existing flowers. High temperatures, sufficient light, and groundwater cause photosynthesis and accumulation of high carbohydrates and it is good for many seed productions. The long rainy season during the flowering season may decrease the production of seeds by inhibiting the spread of pollen, resulting in less pollination. Cloudy weather can cause falling on young fruits, as it reduces the activity of photosynthesis and lowers the supply of carbohydrates. Wetlands facilitate the absorption of nitrogen and other nutrients.

Soil temperature and $\mathrm{pH}$ are closely related to the growth of plant roots. Soil temperature greatly affects the ability of water absorption by plant roots. The absorption of water by the roots will increase as the soil temperature increases. Water absorption on tropical plants occurs at a temperature of 5-70 degrees Celcius. The distinction appears because of the ability of plant adaptation. Extremely high temperatures will lead to disruption of plants' physiological activity, e.g., stopping of photosynthesis, respiration, and enzymatic activity; so, the plants will require no water. Low soil temperatures will decrease the rate of roots water absorption, due to reduced transpiration, drastic soil temperature changes inflict water viscosity in cell membranes, therefore, it affects the physiological activity of root cells.

Soil $\mathrm{pH}$ in research area ranged from 4.0 to 12.0. According to Gardner (1991), soil $\mathrm{pH}$ beyond the 5.0-8.0 range potentially had a direct effect in preventing root growth. In such a range, as it is found in most field conditions, the influence is usually indirect. Soil $\mathrm{pH}$ of less than 6.0 increases $\mathrm{Al}, \mathrm{Mg}$, and $\mathrm{Fe}$, which can be toxic, and can reduce root growth.

In conclusion, there is a difference in the characteristics of $T$. catappa plants due to differences in altitude and the size of photosynthetic parts of plants. The findings of this study imply that exploration and characterization of $T$. catappa plants are still needed to reveal the potential of its germplasm as well as the development of cultivation technology and the further processing of its production. The economic benefits of $T$. catappa trees are still unknown by the community, but the ecological benefit is known, e.g., as a shade plant. The fruits that are yellow to reddish when ripe are important for researcher to identify their specific functions. Therefore, ecological characterization, physiology, morphology, and even molecular of $T$. catappa plant is very necessary, especially since in Indonesia generally, and East Kalimantan especially, T. catappa is only planted as shade plants on the edge of the road. T. catappa has not been utilized as a forestry plant.

\section{ACKNOWLEDGEMENTS}

Many thanks to the Directorate General of Research and Strengthening Research and Development of the Indonesian Ministry of Research, Technology and Higher Education for the research grants provided to the researcher. And we would like to express our gratitude to 
Riyayatsyah and Ibnu Suyuti, Rizky Dirga, Irwan, Muhammad Said, and Anjas Aswar for their assistance in the field. Many thanks to the members of Silviculture Laboratory, Faculty of Forestry, Mulawarman University, Samarinda, Indonesia for supporting this project.

\section{REFERENCES}

Akpakpan AE, Akpabio UD. 2012. Evaluation of proximate composition, mineral element and anti-nutrient in almond (Terminalia catappa) seeds. Res J Appl Sci 7 (9-12): 489-493. DOI: 10.3923/rjasci.2012.489.493

Apata DF. 2011. Effect of Terminalia catappa Fruit Meal Fermented by Aspergillus niger as Replacement of Maize on Growth Performance, Nutrient Digestibility, and Serum Biochemical Profile of Broiler Chickens. Department of Animal Production, University of Ilorin, Ilorin, Nigeria.

Arx GV, Dobbertin M, Rebetez M. 2012. Spatio-temporal effects of forest canopy on understory microclimate in a long-term experiment in Switzerland. Agric For Meteor 166-167 (2012): 144- 155. DOI: 10.1016/j.agrformet.2012.07.018

Dos-Santos OV, Lorenzo ND, Da Silva Lannes SC. 2016. Chemical, morphological, and thermogravimetric of Terminalia catappa Linn. Food Sci Technol Campinas 36 (1): 115-158. DOI: 10.1590/1678457X.0090
Edwin-Wosu NL, Omara-Achong T, Nyannannyo BL. 2013. Ecogeographical amplitude and habitat of two species of Genus Terminalia (Combretaceae) in the Central Niger Delta Areas in Rivers State. J Appl Sci Environ Manag 17 (1): 75-80.

Goldsworthy PR, Fisher NM. 1992. The Physiology of Tropical Field Crops. (In Bahasa Indonesia. Translator: Tohari). Gadjah Mada University Press. Yogyakarta.

Hayward DF. 1990. The phenology and economic potential of Terminalia catappa L. in South-Central Ghana. Vegetatio 90: 125-131.

Henn JJ, McCoy MB, Vaughan CS. 2014. Beach almond (Terminalia catappa, Combretaceae) seed production and predation by Scarlet Macaws (Ara macao) and Variegated Squirrels (Sciurus variegatoides). Rev Biol Trop (Int J Trop Biol) 62 (3): 929-938. DOI: 10.15517/rbt.v62i3.14060

Morton JF. 1985. Indian Almond (Terminalia catappa) Salt-Tolerant, Useful, Tropical Tree with "Nut" Worthy of Improvement. Econ Bot 39 (2): 101-112. DOI: 10.1007/BF02907830

Oboh B, Ogunkanmi B, Olasan L. 2008. Phenotype diversity in Terminalia catappa from South Western Nigeria. Pakistan J Biol Sci 11 (1) 135-138. DOI: 10.3923/pjbs.2008.135.138

Raju AJS, Lakshmi PV, Ramana KV. 2012. Reproductive ecology of Terminalia pallida Brandis (Combretaceae), an endemic and medicinal tree species of India. Curr Sci 102 (6):-.

Setyawan AD. 1999. Status of the Alpinia genus taxonomy based on morphological characteristics, anatomy, and chemical essential oil content. BioSMART 1 (1): 31-40. [Indonesian]

Thomson LAJ, Evans B. 2006. Terminalia catappa. Species Profiles for Pacific Island Agroforestry. www.traditionaltree.org 